\title{
A New Species of Leucheria (Asteraceae, Mutisieae) from Chile
}

\author{
Author(s): Liliana Katinas, María Cristina Tellería, Jorge V. Crisci
}

Source: Novon: A Journal for Botanical Nomenclature, 18(3):366-369. 2008.

Published By: Missouri Botanical Garden

DOI: http://dx.doi.org/10.3417/2006108

URL: http://www.bioone.org/doi/full/10.3417/2006108

BioOne (www.bioone.org) is a nonprofit, online aggregation of core research in the biological, ecological, and environmental sciences. BioOne provides a sustainable online platform for over 170 journals and books published by nonprofit societies, associations, museums, institutions, and presses.

Your use of this PDF, the BioOne Web site, and all posted and associated content indicates your acceptance of BioOne's Terms of Use, available at www.bioone.org/ page/terms_of_use.

Usage of BioOne content is strictly limited to personal, educational, and noncommercial use. Commercial inquiries or rights and permissions requests should be directed to the individual publisher as copyright holder. 


\title{
A New Species of Leucheria (Asteraceae, Mutisieae) from Chile
}

\author{
Liliana Katinas \\ División Plantas Vasculares, Museo de La Plata, Paseo del Bosque s/n, B1900FWA La Plata, \\ Argentina. katinas@fcnym.unlp.edu.ar
}

María Cristina Tellería

Laboratorio de Sistemática y Biología Evolutiva (LASBE), Museo de La Plata, Paseo del Bosque s/n, B1900FWA La Plata, Argentina. mariatelleria@fcnym.unlp.edu.ar

Jorge V. Crisci

División Plantas Vasculares y Laboratorio de Sistemática y Biología Evolutiva (LASBE), Museo de La Plata, Paseo del Bosque s/n, B1900FWA La Plata, Argentina. crisci@fcnym.unlp.edu.ar

Abstract. A new species of Leucheria Lagasca (Asteraceae, Mutisieae), L. graui Katinas, M. C. Tellería \& Crisci, with glutinous habit and yellow corollas is described and illustrated. This would be the only species within Leucheria with yellow corollas. The pollen of the new species is also described and illustrated; it belongs to the Oxyphyllum Philippi pollen type and has similar characteristics to other species of Leucheria. The new species appears to be morphologically close to L. apiifolia Philippi, which belongs to the relatively primitive $L$. glacialis (Poeppig ex Lessing) Reiche evolutionary line of dry environments.

Key words: Asteraceae, Chile, IUCN Red List, Leucheria, Mutisieae.

The genus Leucheria Lagasca comprises 47 species distributed from Peru to the Falkland Islands (Islas Malvinas) in Argentina (Crisci, 1976). These plants belong to the subtribe Nassauviinae (Asteraceae, tribe Mutisieae, or subfamily Mutisioideae; Jeffrey, 2007; Katinas et al., in press), which is characterized by its genera with capitula florets all bilabiate; the styles cleft into two truncate branches, each branch with an apical crown of rounded papillae; and the exine of the pollen grains distinctly bilayered, with the ectosexine and the endosexine clearly columellate (Crisci, 1974; Tellería et al., 2003). The species of Leucheria are typically distributed in the Andes, in extra-Andean areas of Chile, and in the Patagonian steppe. Leucheria is distinguished from other members of Nassauviinae by its herbaceous habit, paleae in the capitula of some species, involucre in two or more series, glabrous receptacle, florets rarely yellow, and capillary pappus in one series, frequently plumose. The pollen grains of Leucheria are of the Oxyphyllum Philippi pollen type, with the ectosexine and endosexine of the same thickness, separated by a thin internal tectum in zigzag, a characteristic shared with the genera Nassauvia Commerson ex Jussieu, Triptilion Ruiz \& Pavón, and Polyachyrus Lagasca (Crisci, 1974). Recent molecular studies (Katinas et al., 2008) show a sister relationship between Leucheria and Polyachyrus, and both are sister of Moscharia Ruiz \& Pavón.

The species described here-Leucheria graui Katinas, M. C. Tellería \& Crisci-was discovered around Laguna del Maule in central Chile, during a field trip of the German botanist Jürke Grau. The striking characteristic of this new species is the yellow color of the corollas, a very rare feature since all the species of Leucheria described until now have white, pink, red, purple, or blue corollas. Also, L. graui is one of the few species of Leucheria covered exclusively with glandular hairs, since most species have white lanose pubescence (frequently the nonglandular hairs are mixed with glandular hairs).

Leucheria graui Katinas, M. C. Tellería \& Crisci, sp. nov. TYPE: Chile. Región VII, Prov. Maule: Laguna del Maule, rocas al O de la laguna, 2300 m, 25 Jan. 1981, J. Grau 2893 (holotype, LP; isotypes, CONC, M not seen). Figures 1, 2.

Ab Leucheria apiifolia Philippi differt folii lobis profundis, angustioribus, floribus 50 ad 60 , flavescentibus, et fructus trichomatibus distinctus ex cellulis 4 compositis.

Perennial, caulescent herbs, $15-30 \mathrm{~cm}$ tall, stems striate, densely glandulose. Leaves simple, bipinnatisect, basal leaves in a rosette, upper leaves alternate, herbaceous, densely glandulose on both surfaces, glandular hairs uniseriate, margin planate, sessile, pseudopetiolate, pinnately veined, veins conspicuous 


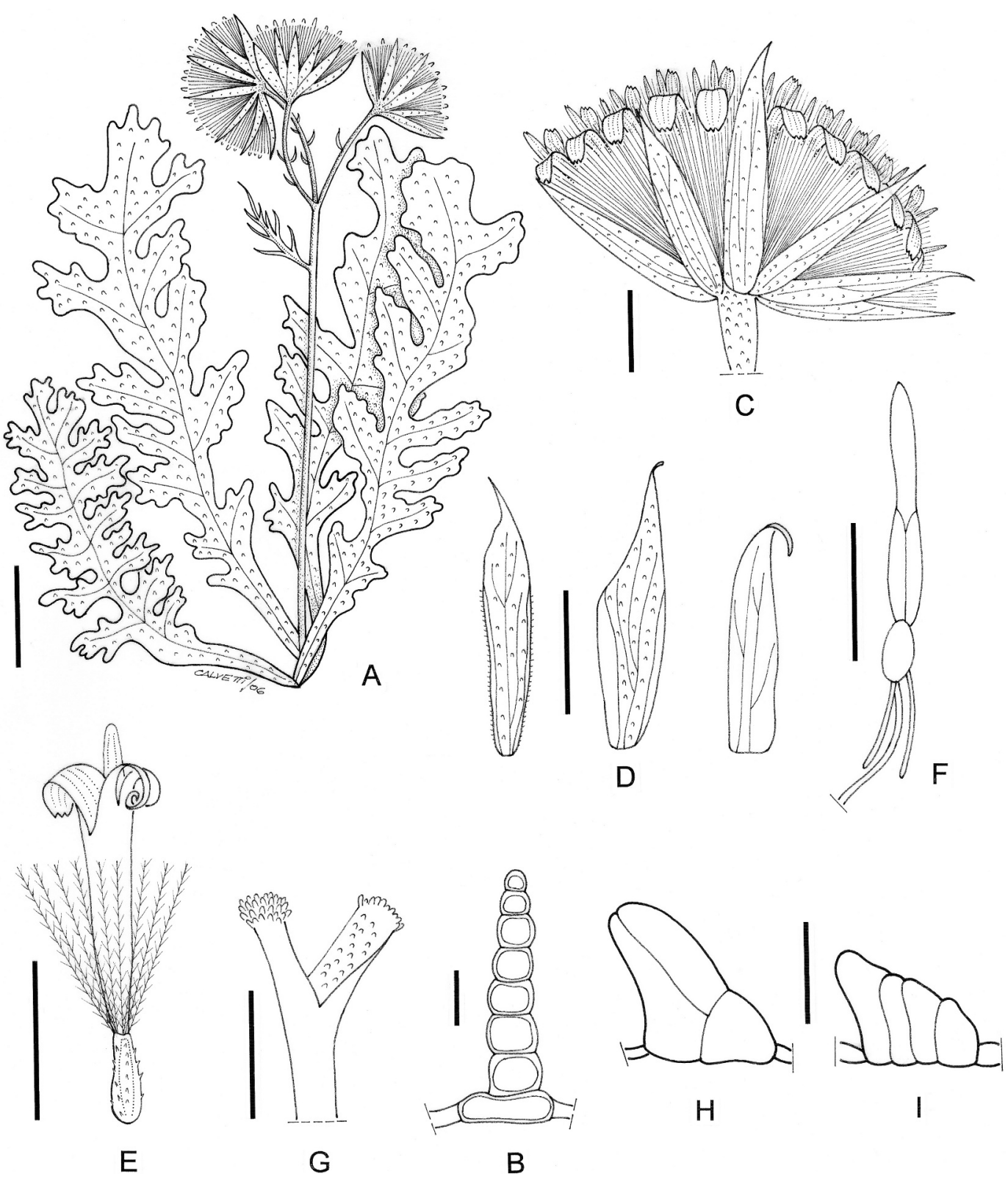

Figure 1. Leucheria graui Katinas, M. C. Tellería \& Crisci. - A. Habit. -B. Vegetative glandular hair. —C. Capitulum. -D. Phyllaries of the involucre. - E. Floret with cypsela and pappus. - F. Stamen. - G. Style apex. - H. Cypsela basic twin hair. - I. Cypsela crenate twin hair. From the holotype Grau 2893 (LP). Scale bars: A $=2 \mathrm{~cm} ; \mathrm{B}, \mathrm{H}, \mathrm{I}=50 \mu \mathrm{m} ; \mathrm{C}-\mathrm{E}=$ $5 \mathrm{~mm} ; \mathrm{F}=2 \mathrm{~mm} ; \mathrm{G}=1 \mathrm{~mm}$.

on both surfaces; blades oblong to elliptic, 6-17 $\times$ $1.5-8 \mathrm{~cm}$, segments narrowly oblong, narrowly oblanceolate, or oblanceolate, pinnatifid to pinnatisect, $0.5-3.5 \times 1.5-2 \mathrm{~cm}$, apex acute or acuminate. Capitulescences corymbose; capitula hemispheric, 12-15 × 15-26 mm, homogamous, discoid, pedunculate, peduncle bracteate; receptacle naked; involucre 2 - or 3 -seriate, $10-11 \times 16-30 \mathrm{~mm}$, phyllaries narrowly oblong to elliptic, long attenuate at the apex, margin shortly ciliate, veins purple, first series 5 to 7 , 10-13 $\times 1.5-3 \mathrm{~mm}$, scarious at the margins, glandulose, second series 2 to $5,10-12 \times$ ca. $2 \mathrm{~mm}$, glandulose, scarious at the margins, third series 0 to 3 , 10-12 × 1.5-2 mm, glabrous, completely scarious. Florets isomorphic, bisexual, 50 to 60 per capitulum, corollas bilabiate, yellow, tube $4-8 \mathrm{~mm}$, outer lip 


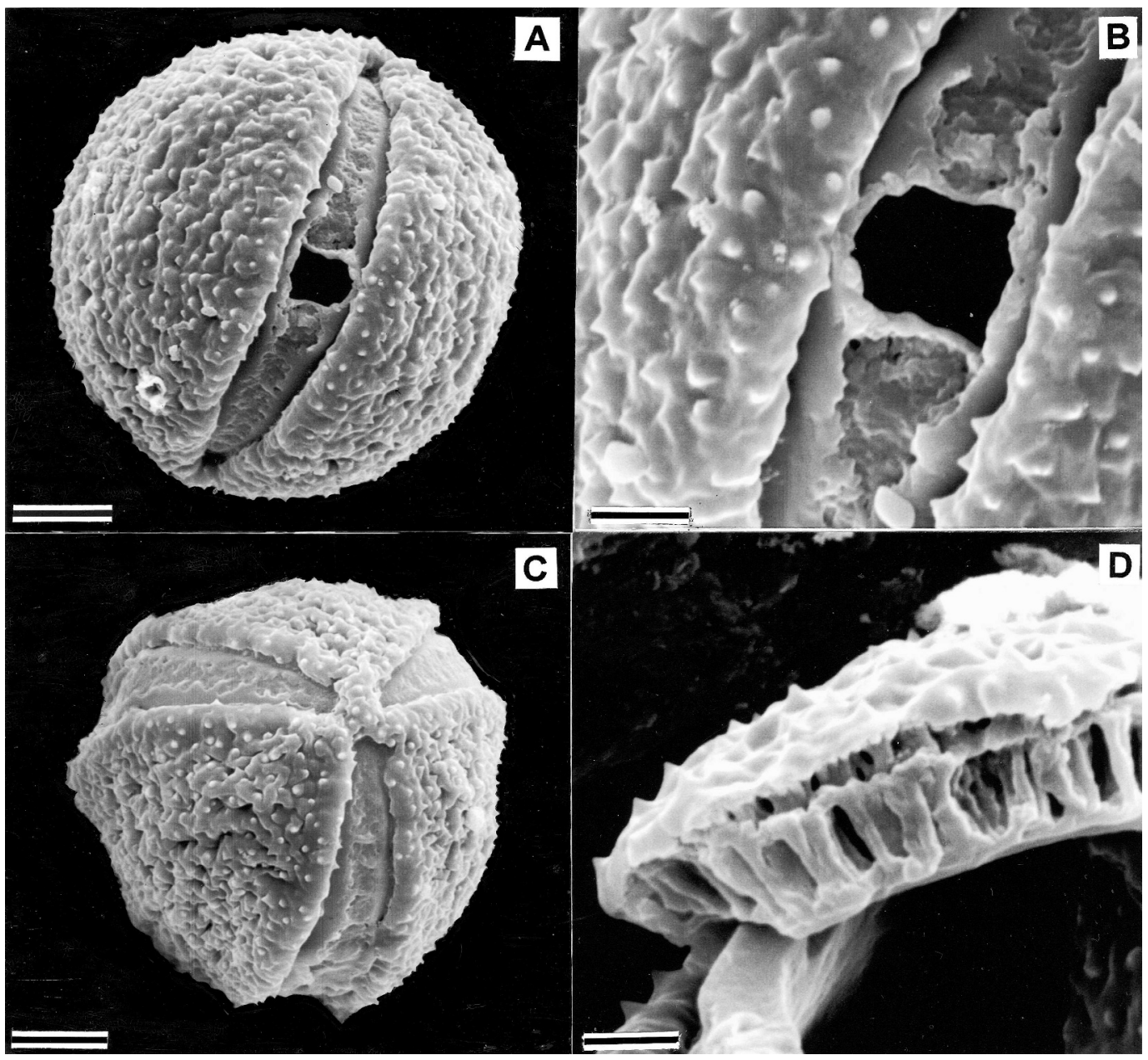

Figure 2. Pollen of Leucheria graui Katinas, M. C. Tellería \& Crisci. - A. Equatorial view. -B. Detail of aperture and pollen surface. - C. Polar view. - D. Exine structure from a broken grain. From the holotype Grau 2893 (LP). Scale bars: A, C $=5 \mu \mathrm{m} ; \mathrm{B}, \mathrm{D}=2 \mu \mathrm{m}$.

3-toothed, 4-7 mm, inner lip bifid, 4-7 mm; stamens inserted in the corolla throat, anthers $4-5.5 \mathrm{~mm}$, apical appendage lanceolate, acute, tails smooth, ca. $2 \mathrm{~mm}$, conspicuous antheropodium in the insertion of the filament to the anthers; style $8-9 \mathrm{~mm}$, cleft into 2 truncate branches, each branch $1-1.5 \mathrm{~mm}$, with an apical crown of rounded papillae, nectariferous disc at the base of the style. Cypselae (immature) 2-2.5 mm, constricted at the apex by an epigynous disc, 5costate, pubescent (typical and atypical twin hairs, rarely glandular hairs biseriate); pappus $6-6.6 \mathrm{~mm}$, uniseriate, bristles united at the base, capillary, plumose.

Pollen (light microscopy) spheroidal to subprolate, spheroidal in equatorial view, circular in polar view, medium size, polar diameter $\times$ equatorial diameter $=$ 29-35 × 28-32 $\mu \mathrm{m}$; tricolporate, colpi long, with microgranulate membrane; endoaperture lalongate; exine Oxyphyllum type, $3 \mu \mathrm{m}$ thick, nexine thickened at level of endoaperture; pollen (SEM) surface imperforate, microechinate, with rugulate aspect; colpi entirely covered with scabrate membrane.

Distribution and habitat. Leucheria graui is known only from the type location in rocky places around the Laguna del Maule in central Chile, at about $2300 \mathrm{~m}$ in elevation.

IUCN Red List category. This species is only known by a single collection (the type specimens). The plant is very scarce and grows exclusively in the volcanic rock crevices around Laguna del Maule in Chile (Jürke Grau, pers. comm.); therefore, according to the IUCN Red List criteria (IUCN, 2001), Leucheria graui should be included in the category Vulnerable (VU). 
Table 1. Characters that distinguish Leucheria graui from L. apiifolia.

\begin{tabular}{|c|c|c|}
\hline & L. graui & L. apiifolia \\
\hline Leaf segments & narrowly oblong, narrowly oblanceolate, or oblanceolate & widely oblong \\
\hline No. of florets & 50 to 60 & ca. 36 \\
\hline Corolla color & yellow & white \\
\hline Cypsela trichomes & basic and crenate twin hairs, rarely glandular hairs & basic twin hairs and glandular hairs \\
\hline \multicolumn{3}{|l|}{ Pappus } \\
\hline Bristles & filiform-paleaceous, $0.05-0.10 \mathrm{~mm}$ wide, straight & $\begin{array}{l}\text { filiform, ca. } 0.05 \mathrm{~mm} \text { wide, twisted at } \\
\text { the apex }\end{array}$ \\
\hline Cilia of bristles & long $(0.30-0.50 \mathrm{~mm})$ & short $([0.20-] 0.25[-0.30] \mathrm{mm})$ \\
\hline
\end{tabular}

Etymology. Leucheria graui is named in honor of the German botanist Jürke Grau (b. 1937), an expert on the flora of Chile and collector of the type.

Discussion. Leucheria graui can be distinguished by its glutinous appearance, sweet scent, and yellow florets. Anatomically, it can be also distinguished from the other species of Leucheria by the presence of crenate twin hairs in the cypselae (Freire \& Katinas, 1995); these are characterized by their four hair cells that are cylindrical and united by their longitudinal walls (Fig. 1I). This type of hair can be also found in Acourtia D. Don, another member of the subtribe Nassauviinae (Freire \& Katinas, 1995).

The closest species to Leucheria graui is $L$. apiifolia, endemic to Curicó, Región VII, in Chile; they resemble each other in their caulescent habit, corymbose capitulescence, and glandular pubescence. The species differ in characters of leaves, florets, cypsela, and pappus (Table 1). Leucheria graui is also close to L. salina (Rémy) Hieronymus, which inhabits northwestern and western Argentina and central Chile. Leucheria graui differs by the stems sparsely foliose at the base, larger involucres $(10-11 \times 16-$ $30 \mathrm{~mm}$ ), and yellow corollas. The pollen exine type, shape and size of the pollen grains, and aperture features of L. graui are very similar to those of the other species of Leucheria.

Crisci (1976) distinguished nine evolutionary lines within Leucheria. The new species belongs to the $L$. glacialis (Poeppig ex Lessing) Reiche line, constituted by L. apiifolia, L. congesta D. Don, L. glacialis, L. landbeckii (Philippi) Reiche, L. paniculata Poeppig ex Lessing, and L. runcinata D. Don. This line consists of caulescent plants, generally with numerous capitula (three to 20). According to Crisci (1976), the $L$. glacialis line is relatively primitive and probably evolved from the L. thermarum (Philippi) Philippi evolutionary line (L. coerulescens J. Rémy, L. magna Philippi, and L. thermarum) from Nothofagus Blume (southern beech) forests. The members of the $L$. glacialis line inhabit dry areas north of the Nothofagus forests, above $2000 \mathrm{~m}$ in Chile and Argentina.

Acknowledgments. We thank Diego G. Gutiérrez for a critical reading of this manuscript and Hugo Calvetti for preparation of the illustrations. Thanks are also due to Vicki Funk, one anonymous reviewer, and the scientific editor of Novon, Victoria C. Hollowell. The John Simon Guggenheim Foundation (LK), the National Geographic Society (grant \#7646-04), and Consejo Nacional de Investigaciones Científicas y Técnicas are also acknowledged.

\section{Literature Cited}

Crisci, J. V. 1974. A numerical-taxonomic study of the subtribe Nassauviinae (Compositae, Mutisieae). J. Arnold Arbor. 55: 568-610.

- 1976. Revisión del género Leucheria (Compositae: Mutisieae). Darwiniana 20: 9-126.

Freire, S. E. \& L. Katinas. 1995. Morphology and ontogeny of the cypsela hairs of Nassauviinae (Asteraceae, Mutisieae). Pp. 107-143 in D. J. N. Hind, C. Jeffrey \& G. V. Pope (editors), Advances in Compositae Systematics. Royal Botanic Gardens, Kew.

IUCN. 2001. IUCN Red List Categories and Criteria Version 3.1. Prepared by the IUCN Species Survival Commission. IUCN, Gland, Switzerland, and Cambridge, United Kingdom.

Jeffrey, C. 2007. Compositae: Introduction with key to tribes. Pp. 61-87 in K. Kubitzki (editor), The Families and Genera of Vascular Plants, Vol. 8. Springer Verlag, Berlin.

Katinas, L., J. V. Crisci, R. Schmidt Jabaily, C. Williams, J. Walker, B. Drew, J. M. Bonifacino \& K. J. Sytsma. 2008. Evolution of secondary heads in Nassauviinae (Asteraceae, Mutisieae). Amer. J. Bot. 95: 229-240.

—, J. Pruski, G. Sancho \& M. C. Tellería. The Subfamily Mutisioideae (Asteraceae). Bot. Rev. (in press).

Tellería, M. C., E. Urtubey \& L. Katinas. 2003. Proustia and Lophopappus (Asteraceae, Mutisieae): Generic and subtribal relationships based on pollen morphology. Rev. Palaeobot. Palynol. 123: 237-246. 